\title{
Alojz Cindrič: \\ OD IMATRIKULACIJE DO PROMOCIJE \\ Ljubljana, Znanstvena založba Filozofske fakultete, 2015
}

Ob bližajoči se stoletnici Filozofske fakultete in Univerze v Ljubljani je bila zasnovana zbirka Historia facultatis. Prvo delo v tej zbirki je monografija, ki je nastala ob podrobnem študiju arhivskega gradiva o doktorskih študentih in nosi podnaslov Doktorandi profesorja Franceta Vebra na Oddelku za filozofijo Filozofske fakultete Univerze v Ljubljani v luči arhivskega gradiva 1919-1945.

Dr. Cindrič je že s svojimi prejšnjimi raziskavami o izobraževanju na univerzi ponudil poglobljen vpogled v akademsko zgodovino, v značilnosti življenja študentov in njihovega izobraževanja na dunajski univerzi. Svoje raziskovanje zgodovine izobraževanja je nadaljeval $\mathrm{z}$ analizo doktorskega študija na ljubljanski univerzi prek mentorskega dela profesorja Vebra, pri katerem je doktoriralo 23 študentov, med njimi tudi dva za pedagogiko pomembna avtorja, in sicer Stanko Gogala in Leon Žlebnik. Cindričevo delo je zanimivo z različnih zornih kotov, ne le kot osvetlitev filozofskega dogajanja v Ljubljani med obema vojnama, saj njegova spoznanja prispevajo več področjem znanja, med temi tudi pedagogiki in andragogiki. Naslov zadnje monografije označujeta dve točki v doktorskem študiju, imatrikulacija, ki pomeni vpis v matriko, in promocija, ki pomeni svečano podelitev doktorske listine.

Besedilo je razdeljeno na uvodni del, ki opisuje ustanovitev univerze, arhivsko gradivo in potek doktorskega študija, osrednji del, ki predstavlja 23 doktorandov, temu sledijo priloge in viri, zadnji del sestavljata dve besedili o Vebrovem delu, ki sta ju prispevala Bojan Žalec in Tanja Pihlar. Uvodne besede Knjigi na pot je napisal Andrej Ule. Monografija prinaša mnogo zanimivosti, od tako podrobnih, kot je obseg disertacije - disertacije so bile dolge med 40 in 130 folianti, nekatere tudi 400 foliantov - do splošnejših, npr. o uporabi jezika, odnosih med mentorjem in doktorandom, kar je tudi izraz posebnih pristopov pri raziskovanju arhivskega gradiva in pripravi tega za objavo.

Značilnosti doktorskega študija spremljamo prek predstavitev 23 osebnih zgodb, ki bi jih lahko razumeli kot študije primerov. Skozi biografski pristop so osvetljeni doktorandi: S. Leben, K. Jug, A. Sodnik, N. Berus, F. Čibej, A. Špakovskij, S. Gogala, V. Bartol, M. Hribar, 1. Benko, F. Žekar, C. Logar, F. P. Garantini, E. Hrovat, H. Lešanc, M. Rakočević, L. Puš, L. Jurković, L. Žlebnik, R. Trofenik, V. K. Pandžić, L. Potočnik, J. Premrov. Kot zanimivost lahko navedemo, da je Alma Sodnik opravljala doktorski izpit iz filozofije in 
pedagogike in da je Premrov raziskoval »izseljensko dušo«, kar je danes spet aktualna tema. Stanko Gogala je leta 1921 vpisal filozofijo in botaniko, opravljal rigoroz iz pedagogike, promoviran je bil leta 1925. Iz izpisa njegovih študijskih predmetov vidimo, da se je že v prvem letniku (1921/22) pri prof. Ozvaldu v pedagoškem proseminarju ukvarjal s problemom discipline $\mathrm{v}$ šoli in življenju, kar - mimogrede - kaže na dolgotrajnost problema, s katerim se ukvarjajo v sodobnih šolah. Stanko Gogala v svojem življenjepisu napiše, da je njegov »duševni razvoj na univerzi« v zvezi s prof. Vebrom, ki ga je »začutil kot svojega duševnega učitelja in vodnika«. Njegov mentor pri doktoratu pa je v oceni disertacije zapisal, da »avtor $\mathrm{s}$ to vedo ni samo docela seznanjen, temveč jo sme s pridom uporabljati na pristojnih popriščih psihologije in spoznavne teorije«. Prof. Ozvald se je z oceno strinjal, dopisal pa je, da je jezikovna oblika »pričujoče disertacije mestoma precej pomanjkljiva«. Leon Žlebnik, filozof in pedagog, je doktoriral z nalogo Emocionalna struktura eudajmonije. Njegovo nalogo so Veber, Ozvald in Grošelj ocenili kot uspešno delo. V opisih študija in izpitov (načina spraševanja, zapisnikov, življenjepisov ob prijavi) lahko pri različnih doktorandih zaznamo tako vsebinsko raznolikost in časovni potek študija kot hierarhičen odnos med učitelji in študenti. Arhivsko gradivo je dosledno predstavljeno, vendar omogoča tudi domišljijska vprašanja. Pri ocenah se sprašujemo, kaj je člane komisije navduševalo, ko so napisali, da »je naravnost vzbujal moje občudovanje«, kdove s čim niso bili zadovoljni, kaj se je dogajalo na zagovorih ... Pri prof. Vebru je doktoriral tudi Vladimir Bartol, ki je opravljal doktorski izpit iz filozofije in biologije ter rigoroz iz pedagogike. V njegovi oceni je napisano, da »splošno pravilno uporablja svoje lepo psihološko znanje za reševanje svojih mejnih vprašanj, dasi ga sicer njegova prevelika vnetost na važnih točkah vede predaleč ...«, kar nam osvetli jezik zapisov in tudi način ocenjevanja.

Profesor Veber je bil mentor, ki je deloval kot vzor (»duševni učitelj« z besedami S. Gogale) mnogim študentom, bil je »eruptiven predavatelj«. V zadnjem delu monografije Bojan Žalec opiše delo Vebrovih doktorandov z vzklikom: »Kakšno bogastvo!« Lahko se le strinjamo z njim in dodamo, da je Cindričeva raziskava uvod v nadaljnje spoznavanje univerzitetnega študija, kar bi bilo ob soočanju s problemi sodobnih reform zelo dobrodošlo (spo)znanje. Predstavitev Vebrovih doktorandov je večplastno informiranje bralcev o poteku študija in o »interdisciplinarnem povezovanju « pri raziskovanju. Monografija subtilno in s filigranskim pristopom prikaže sistem doktorskega študija in delo profesorja, »ki ni učil neke določene filozofije, ampak je spodbujal k samostojnemu in kritičnemu razmišljanju«, kot zapiše T. Pihlar.

Nives Ličen 